\title{
CONTROLLED RELEASE FERTILIZER IN THE GROWTH OF Moringa oleifera LAM. SEEDLINGS
}

\author{
Thuanny Lins Monteiro Rosa ${ }^{1 *}$, Renan Baptista Jordaim², Rodrigo Sobreira Alexandre ${ }^{3}$, Caroline Palacio de Araujo ${ }^{1}$, \\ Fabrício Gomes Gonçalves ${ }^{3}$, José Carlos Lopes ${ }^{2}$ \\ ${ }^{1}$ Federal University of Espírito Santo, Graduate Program in Forest Science, Jerônimo Monteiro, Espírito Santo, Brazil - thuannyer@gmail.com*; \\ carolinepalacio@yahoo.com.br \\ ${ }^{2}$ Federal University of Espírito Santo, Department of Agronomy, Alegre, Espírito Santo, Brazil - renan_jordaim@ @otmail.com; \\ jcufes@bol.com.br \\ ${ }^{3}$ Federal University of Espírito Santo, Department of Forestry and Wood Sciences, Jerônimo Monteiro Espírito Santo, Brazil - \\ rodrigosobreiraalexandre@gmail.com; fabricio.goncalves@ufes.br
}

Received for publication: 05/01/2017 - Accepted for publication: 04/04/2018

\begin{abstract}
Moringa oleifera presents important medicinal properties, and its seeds are used to treat water for human consumption and wastewater. The aim of the present study was to analyze the initial growth of M. oleifera seedlings in enriched commercial substrate with differing doses of controlled release fertilizer. The experimental was designed in randomized blocks, with four repetitions of 16 seedlings each. The treatment used doses of controlled release fertilizer, with $0 ; 2 ; 4 ; 6$; and $8 \mathrm{~kg} \mathrm{~m}^{-3}$ of commercial substrate. A hundred days after installing the experiment, the following characteristics were analyzed: height of the aerial part; diameter of the root collar; length; volume; and dry mass of the roots and aerial part. Additionally, the relation between the height of the aerial part and the diameter of the root collar and the Dickson quality index (DQI) were determined. The data was submitted to analysis of variance and to the Shapiro-Wilk test to verify the normality and regression. Controlled release fertilizer at a dose of $5.37 \mathrm{~kg} \mathrm{~m}^{-3}$ of substrate is recommended for M. oleifera seedling production.
\end{abstract}

Keywords: Moringa, fertilizing, propagation, seeds.

\section{Resumo}

Fertilizante de liberação controlada no crescimento de mudas de Moringa oleífera Lam. Moringa oleifera apresenta importantes propriedades medicinais e suas sementes são utilizadas no tratamento de água para consumo humano e águas residuais. Objetivou-se neste trabalho analisar o crescimento inicial de mudas de M. oleifera em substrato comercial enriquecido com diferentes doses de fertilizante de liberação controlada. O delineamento experimental utilizado foi o em blocos casualizados, com quatro repetições de 16 mudas cada. $\mathrm{O}$ tratamento utilizado foram doses de fertilizante de liberação controlada, sendo elas $0 ; 2 ; 4$; 6 e $8 \mathrm{~kg} \mathrm{~m}^{-3}$ de substrato comercial. Decorridos 100 dias da montagem do experimento, foram analisados: altura da parte aérea; diâmetro do coleto; comprimento; volume; e massa seca de raiz e da parte aérea. Também, foram determinados a relação altura da parte aérea e diâmetro do coleto e o índice de qualidade de Dickson (IQD). Os dados foram submetidos à análise de variância e ao teste de Shapiro-Wilk para verificação da normalidade e regressão. Para a produção de mudas de $M$. oleifera, recomenda-se o fertilizante de liberação controlada na dose de $5,37 \mathrm{~kg} \mathrm{~m}^{-3}$ de substrato.

Palavras-chave: Moringa, adubação, propagação, sementes.

\section{INTRODUCTION}

The species Moringa oleifera Lam. (Moringaceae) is typical to India and commonly found in tropical and subtropical regions (LEONE et al., 2015). Additionally, it has high nutritional value and excellent medicinal properties,

FLORESTA, Curitiba, PR, v. 48, n.3. p. 303- 310, jul/set. 2018

Rosa. T.L.M. et.al.

ISSN eletrônico 1982-4688

DOI: $10.5380 /$ rf.v.48 i3.50063 
which has led to it being labelled a miracle tree (GOPALAKRISHNAN et al., 2016). Its leaves are a rich source of nitrogen, calcium, potassium, phosphorous, and vitamins (BASRA et al., 2015), and its seeds are rich in oils, proteins, and fibers (LEONE et al., 2016).

The powder from M. oleifera seeds, which has a substance with coagulant properties in its make up that is soluble in water, can be used as a natural coagulant, generating a significant reduction in turbidity and apparent watercolor (NDABIGENGESERE et al., 1995; ARANTES et al., 2015). Scarcity of treated water is currently an issue that mainly affects developing countries and drives a search for alternative, cheap and sustainable means to resolve this public health problem (SÁNCHEZ-MARTÍN et al., 2012). Therefore, the use of this plant extract is justified to substitute aluminum sulfate, used as an industrial coagulant in developing countries (SÁNCHEZ-MARTÍN et al., 2012), reducing the cost of water treatment. Other uses of $M$. oleifera seeds reported in the literature include the production of biodiesel (PINTO et al., 2012) and the treatment of water for the dairy industry (VIEIRA et al., 2010).

The success of its cultivation depends directly on the silvicultural procedures adopted, amongst which we find the methods used in seedling production. Consequently, studies to identify substrates that provide the nutrients necessary for the development of quality seedlings are important (CECONI et al., 2007; HE et al., 2016; PACHECO et al., 2016).

Controlled release fertilizers are an interesting alternative, since they provide nutrients for the soil in a gradual manner, making them accessible for plants over an extended period, in comparison with mineral fertilizers. (TIAN et al., 2016). This characteristic allows this type of fertilizer to be applied in greater quantities and less frequently, reduce labor costs in the parcel (TIAN et al., 2016). Additionally, it is being tested for seedling production in nurseries as well as in final plantations (LANG et al., 2011).

Controlled release fertilizers contain granules that are completely covered by a film, normally an elastic polymer. The release of its nutrients occurs through a diffusion process that guarantees its availability in a form adequate for the requirements of the cultures, further minimizing losses resulting from leaching and the damaging effects of salinity (CHEN et al., 2018).

Seedling production employing controlled release fertilizers allows a regulation of the input of nutrients that meets the needs of the plant over time and provides all the substances necessary for their development while still young. This factor contributes to the production of seedlings with greater quality and resistance in the field, given that they are less susceptible to pests and diseases that normally attack debilitated plants (HUBER; JONES, 2013).

Therefore, the objective of the present study is to analyze the initial growth of $M$. oleifera seedlings in commercial substrate enriched with controlled release fertilizer.

\section{MATERIAL AND METHODS}

The experiment was conducted in the Forestry Nursery of the Center for Agrarian Sciences and Engineering at the Federal University of Espírito Santo (UFES), situated on the BR 482, municipality of Alegre (state of Espírito Santo, Brazil), and located at the coordinates $20^{\circ} 45^{\prime} 02^{\prime \prime} \mathrm{S}$ and $41^{\circ} 29^{\prime} 06^{\prime \prime} \mathrm{W}$, at an altitude of $117 \mathrm{~m}$. The climate of the region, according to the Köppen classification, is Cwa, characterized by a dry winter and rainy summer and average annual precipitation of $1,200 \mathrm{~mm}$. The average annual temperature oscillates around $27^{\circ} \mathrm{C}$ (INMET, 2015).

M. oleifera obtained from six matrices from the municipality of Iguatu (state of Ceará, Brazil) at the coordinates $6^{\circ} 13^{\prime} 12^{\prime \prime} \mathrm{S}$ and $39^{\circ} 10^{\prime} 48^{\prime \prime} \mathrm{W}$ were used. The climate of the region, according to the Köppen classification, is BSw'h', hot and semiarid, with two well-defined climatic seasons during the year, rainy and dry. The seeds were acclimatized in plastic bags at environmental temperature $\left(25^{\circ} \mathrm{C}\right)$ for 15 days prior to installation of the experiment.

The experimental was designed in randomized blocks, with four repetitions of 16 seedlings each. The treatments consisted of different doses of controlled release fertilizer (CRF): 0; 2; 4; 6 and $8 \mathrm{~kg}$ of FLC per m m $^{-3}$ of commercial substrate. The chemical composition of the CRF and the commercial substrate is found on Tables 1 and 2, respectively.

Table 1. Chemical analysis of the controlled release fertilizer.

Tabela 1. Análise química do fertilizante de liberação controlada.

\begin{tabular}{|c|c|c|c|c|c|c|c|c|c|c|}
\hline \multicolumn{5}{|c|}{ Macronutrients } & \multicolumn{6}{|c|}{ Micronutrients } \\
\hline $\mathrm{N}$ & $\mathrm{P}_{2} \mathrm{O}_{5}$ & $\mathrm{~K}_{2} \mathrm{O}$ & $\mathrm{Mg}$ & $S$ & $\mathrm{Fe}$ & $\mathrm{Zn}$ & $\mathrm{Cu}$ & $\mathrm{Mn}$ & B & Mo \\
\hline 13 & 6 & 16 & 2 & 29.9 & 0.26 & 0.02 & 0.05 & 0.06 & 0.02 & 0.015 \\
\hline
\end{tabular}


Table 2. Chemical and physical analysis of the commercial substrate.

Tabela 2. Análise química e física do substrato comercial.

\begin{tabular}{|c|c|c|c|c|c|c|c|c|c|c|c|c|}
\hline \multicolumn{13}{|c|}{ Chemical analysis } \\
\hline $\mathrm{N}$ & $\mathrm{P}_{2} \mathrm{O}_{5}$ & $\mathrm{~K}_{2} \mathrm{O}$ & $\mathrm{Ca}$ & $\mathrm{Mg}$ & $\mathrm{S}$ & $\mathrm{Fe}$ & $\mathrm{Zn}$ & $\mathrm{Cu}$ & Mn & B & $\mathrm{pH}$ & OM \\
\hline---- & --------. & $-----\cdot$ & $\%---\cdot$ & ----- & ------ & ---- & 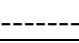 & $-----p p$ & & ------- & & $\%$ \\
\hline 0.63 & 0.77 & 0.40 & 1.17 & 0.60 & 0.27 & 13.9 & 75.0 & 35.0 & 208.0 & 27.0 & 5.10 & 47.4 \\
\hline \multicolumn{13}{|c|}{ Physical analysis } \\
\hline \multicolumn{3}{|c|}{ Humidity $(\%)$} & \multicolumn{3}{|c|}{ Density $\left(\mathrm{g} \mathrm{cm}^{-3}\right)$} & \multicolumn{7}{|c|}{ Water retention capacity $(\%)$} \\
\hline \multicolumn{3}{|c|}{11.89} & \multicolumn{3}{|c|}{0.86} & \multicolumn{7}{|c|}{41.0} \\
\hline
\end{tabular}

OM. Organic material.

The CRF doses were homogenized in the commercial substrate prior to filling the tubes so that all of them received equal amounts of CRF granules, according to the treatment. Sowing was performed at a depth of $0.5 \mathrm{~cm}$ in $280 \mathrm{~cm}^{3}$ polypropylene tubes in a shade house with a $50 \%$ reduction in light intensity.

Forty days after sowing, the trays containing the seedling in the shade house $(50 \%)$ were transferred to the rustification area (full sun), leaving an empty cell between one tube and the next. During the experimental period, the seedlings were irrigated daily using a watering can with the quantity of water controlled to reduce nutrient loss from runoff.

A hundred days after sowing, the following parameters were determined: height of the aerial part $(\mathrm{H})$; seedling root collar height up to the apical gem using a cm ruler; diameter of the root collar (CD) measured at the level of the border of the tube using a digital caliper ( $\mathrm{mm}$ ); root length (RL) in $\mathrm{cm}$; root volume (RV) in $\mathrm{cm}^{3}$, obtained using the principal of displaced fluids (Archimedes' Principle); dry mass of the aerial part (DMAP) and root dry mass (RDM), obtained by drying in a fan forced oven at a temperature of $70{ }^{\circ} \mathrm{C}$ until constant weight was achieved with subsequent weighing on analytic scales (with a precision of $0.0001 \mathrm{~g}$ ); ratio of height of aerial part and diameter of the root collar (H/CD); and Dickson quality index (DQI) (DICKSON et al., 1960). The technical maximum efficiency dose (TMED) was calculated for each variable based on the derivatives of the adjusted equations by regression analysis.

The results were analyzed using the Genes program (CRUZ, 2016). Normality of data was verified using the Shapiro-Wilk test at $5 \%$ level of significance. After verification of normality, the analysis of variance (ANOVA) was performed as well as regression at $5 \%$ probability.

\section{RESULTS}

The CRF had a significant effect on the initial growth of $M$. oleifera seedlings in terms of the diameter of the root collar (CD), total dry mass (TDM) dry mass of the aerial part (DMAP), Dickson quality index (DQI), and height of aerial part and diameter of the root collar ratio (H/CD) (Table 3).

Table 3. Analysis of variance of the biometric features and relations studied for $M$. oleifera seedlings in commercial substrate, depending on the FLC dose 100 days after sowing.

Tabela 3. Análise de variância das características biométricas e relações estudadas em mudas de $M$. oleifera em substrato comercial em função das doses de FLC após 100 dias da semeadura.

\begin{tabular}{lcccccc}
\hline \multirow{2}{*}{ Source of variation } & \multirow{2}{*}{ GL } & \multicolumn{5}{c}{ Mean square } \\
\cline { 3 - 7 } & & CD & TDM & DMAP & DQI & H/CD \\
\hline CRF doses & 4 & $4.20^{*}$ & $247.69^{*}$ & $328.08^{*}$ & $27.43^{*}$ & $2.97^{*}$ \\
Block & 3 & $0.37^{\mathrm{ns}}$ & $90.51^{\mathrm{ns}}$ & $25.71^{\mathrm{ns}}$ & $6.77^{*}$ & $0.27^{\mathrm{ns}}$ \\
Residual & 12 & 0.22 & 41.92 & 10.34 & 1.44 & 0.22 \\
\hline
\end{tabular}

FLORESTA, Curitiba, PR, v. 48, n.3. p. 303- 310, jul/set. 2018

Rosa. T.L.M. et.al.

ISSN eletrônico 1982-4688

DOI: $10.5380 /$ rf.v.48 i3.50063 


\begin{tabular}{lrrrrr}
\hline Overall average & 6.63 & 115.73 & 36.26 & 16.81 & 6.53 \\
\hline $\mathrm{CV}(\%)$ & 7.06 & 5.59 & 8.87 & 7.15 & 7.33 \\
\hline
\end{tabular}

$\mathrm{CRF}=$ controlled release fertilizer; $\mathrm{DF}=$ degree of freedom; $\mathrm{CD}=$ diameter of the root collar $(\mathrm{mm})$; DMAP $=$ dry mass of the aerial part $(\mathrm{g})$; $\mathrm{DQI}=$ Dickson quality index; $\mathrm{H} / \mathrm{CD}=$ ratio of height of aerial part and diameter of the root collar; $*=$ significant at $5 \%$ probability; ${ }^{\text {ns }}=$ non-significant at $5 \%$ probability; $\mathrm{CV}=$ coefficient of variation $(\%)$.

The height of aerial part $(\mathrm{H})$, root length $(\mathrm{RL})$, root volume $(\mathrm{RV})$, and dry mass of root variables for M. oleifera seedlings cultivated in commercial compost substrate with varying CRF doses were not significantly affected (Table 4).

Table 4. Descriptive analyses of the height of aerial part (H), root length (RL), root volume (RV) and dry mass of root (DMR) variables for $M$. oleifera seedlings in commercial substrate as a function of CRF doses.

Tabela 4. Análise descritiva das variáveis altura da parte aérea (H), comprimento de raiz (CR), volume de raiz (VR) e massa seca de raiz (MSR) de mudas de M. oleifera em substrato comercial em função das doses de FLC.

\begin{tabular}{ccccc}
\hline $\mathbf{C R F}\left(\mathbf{k g ~ m}^{-\mathbf{3}}\right)$ & $\mathbf{H}(\mathbf{c m})$ & $\mathbf{R L}(\mathbf{c m})$ & $\mathbf{R V}\left(\mathbf{c m}^{\mathbf{3}}\right)$ & $\mathbf{D M R}(\mathbf{g})$ \\
\hline 0 & $39.905 \pm 2.71$ & $16.61 \pm 0.81$ & $20.11 \pm 2.63$ & $79.46 \pm 2.76$ \\
2 & $42.438 \pm 3.19$ & $17.26 \pm 1.73$ & $22.91 \pm 3.60$ & $88.47 \pm 7.08$ \\
4 & $43.355 \pm 3.09$ & $17.97 \pm 0.77$ & $21.00 \pm 2.42$ & $78.66 \pm 5.59$ \\
6 & $43.855 \pm 1.70$ & $18.30 \pm 1.54$ & $20.32 \pm 2.48$ & $77.42 \pm 6.95$ \\
8 & $42.928 \pm 2.83$ & $18.73 \pm 1.92$ & $19.48 \pm 2.96$ & $73.36 \pm 4.47$ \\
\hline
\end{tabular}

Quadratic behavior as a function of CRF doses can be observed for the CD, DMAP, TDM, DQI, and H/DC ratio values (Figures 1A, 1B, 1C, 1D, and 1E, respectively). Quadratic behavior in the variables until reaching the higher $\mathrm{CD}$ (7.39 mm), DMAP (43.41 g), TDM (122.86 g), and DQI (18.87) values was observed with increasing CRF doses, with the maximum doses of technical efficiency of CRF $\left(5.98 ; 6.46 ; 4.82\right.$ and $5.37 \mathrm{~kg} \mathrm{~m}^{-3}$ of substrate respectively).

The lowest values observed for the variables CD, DMAP, TDM and DQI were $5.12 \mathrm{~mm}, 22.17 \mathrm{~g}, 103.78 \mathrm{~g}$ and 12.85 , respectively, in the absence of CRF, which results presenting a difference of $2.27 \mathrm{~mm}, 21.24 \mathrm{~g}, 19.08 \mathrm{~g}$, and 6.02 from the doses of technical maximum efficiency (Figure 1). Only the H/DC ratio (7.58) was greater in the absence of CRF (Figure 1E). 

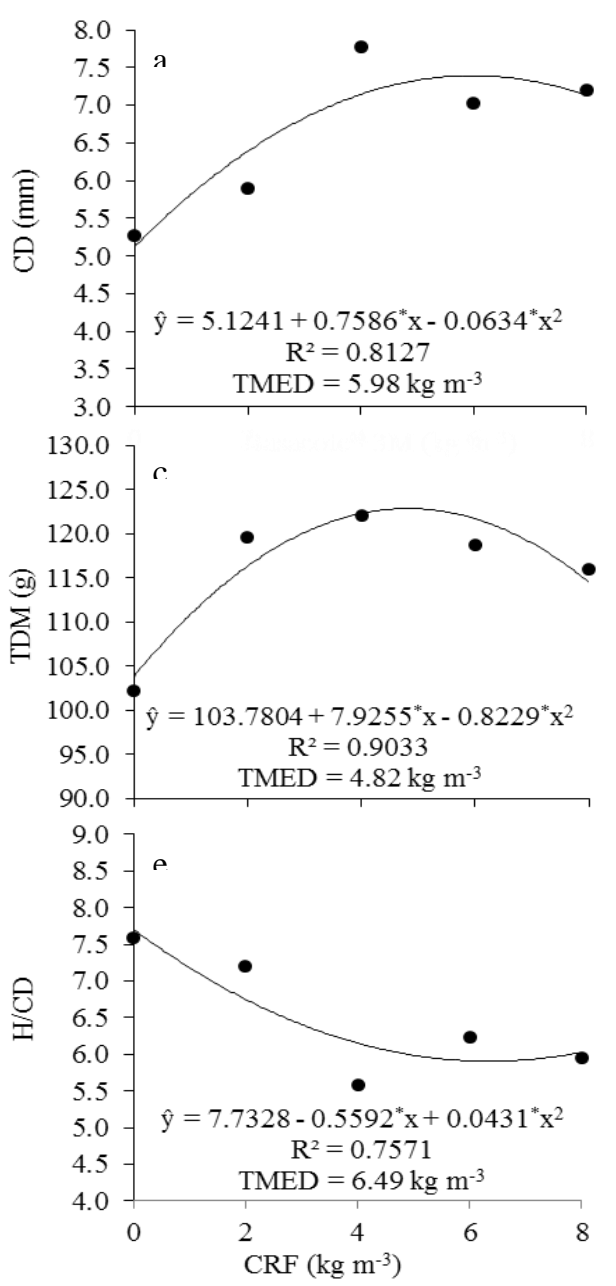

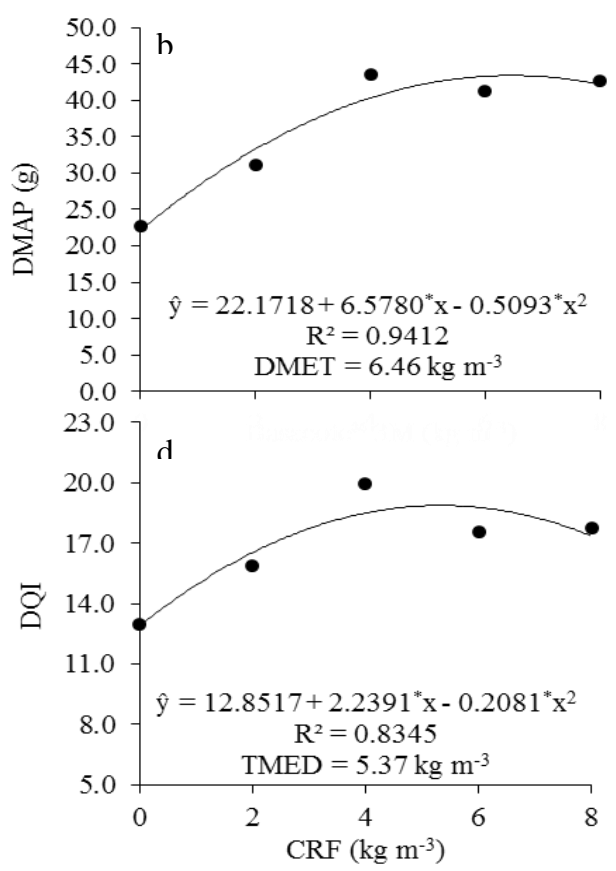

$\left(\mathrm{kg} \mathrm{m}^{-3}\right)$

Figure 1. Diameter of the root collar - CD (a); dry mass of aerial part - DMAP (b); total dry mass - TDM (c); Dickson quality index - DQI (d); and height of the aerial part and diameter of the root collar ratio - H/CD (e) of $M$. oleifera seedlings in commercial substrate as a function of CRF doses. *: Significant at 5\% probability; DTME: Dose of technical maximum efficiency.

Figura 1. Diâmetro do coleto - DC (a), massa seca da parte aérea - MSPA (b), massa seca total - MST (c), índice de qualidade de Dickson - IQD (d), e relação altura da parte aérea e diâmetro do coleto - H/DC (e) de mudas de M. oleifera em substrato comercial em função das doses de FLC. *: Significativo a 5\% de probabilidade; DMET: Dose de máxima eficiência técnica.

The dose corresponding to the minimum point on the quadratic model for the H/CD ratio (5.91) was $6.49 \mathrm{~kg} \mathrm{~m}^{-3}$ (Figure 1E), indicating the greater hardiness of the seedlings.

FLORESTA, Curitiba, PR, v. 48, n.3. p. 303- 310, jul/set. 2018

Rosa. T.L.M. et.al.

ISSN eletrônico 1982-4688

DOI: $10.5380 /$ rf.v.48 i3.50063 


\section{DISCUSSION}

Morphological parameters provide a clearer understanding of quality and material for the survival potential of forest species seedlings in the field. Some characteristics are understood as predictive of species success, such as the stem diameter and number of leaves for example. These characteristics undergo a significant influence from adequate nutritional management during the seedling production period (PACHECO et al., 2016). It is noted in this study that the use of CRF was influential at the doses tested, generating quadratic models, in which optimal doses for the CD, DMAP, TDM and DQI variables in $M$. oleifera seedlings were found $\left(5.98,6.46,4.82,5.37 \mathrm{~kg}_{\text {of }}\right.$ CRF per $\mathrm{m}^{-3}$ of substrate). Above the optimal dose, there was a reduction in the increase of the growth variables analyzed, leading to phytotoxicity.

The CD, DMAP, TDM and DQI variables presented lower values in the treatment without CRF. When the seedlings received different CRF doses, fertilization generated increases in these variables, as was observed in studies with Coffea arabica L., which produced seedlings with greater development and growth when commercial substrate enriched with CRF was used at a concentration of $10 \mathrm{~kg} \mathrm{~m}^{-3}$. This meant that better H/CD, DQI and DMAP values (4.0; 0.21 and 4.7, respectively) were achieved. (MARANA et al., 2008). It was observed therefore, that there was a reduction of seedling diameter growth and total dry mass, caused by an absence of fertilizer. This result showed the importance of this fertilization for the formation of M. oleifera seedlings given that it promoted an increase in their vigor, which implied their adaptation to the field and consequently in success for the propagation of the species.

According to Vieira et al. (2008), $\mathrm{N}$ and $\mathrm{K}$ are the macronutrients that most accumulate in M. oleifera seedlings, followed by $\mathrm{Ca}, \mathrm{S}, \mathrm{P}$ and $\mathrm{Mg}$. They are probably responsible for the growth of the aerial part and the root system in the M. oleifera seedlings in the present study. Studies with other controlled release fertilizers have also been conducted, for example with the formulations 14-14-14 and 15-9-12, which positively influenced the species Anadenanthera colubrina (Veloso) (BRONDANI et al., 2008) and Coffea arabica L., respectively, in the variables H, DMAP, CD, and TDM (MARANA et al., 2008). A lack of $\mathrm{N}$ most affects dry mass production, followed by absences of P, Mg and S (VIEIRA et al., 2007). This indicates that nutritional levels are important for the formation of quality seedlings and in contributing to dry mass accumulation.

A higher $\mathrm{CD}$ indicates a higher chance of survival for the seedling when placed into the field (DELARMELINA et al., 2014). A value of $6.1 \mathrm{~mm}$ for CD was observed for M. oleifera seedlings cultivated in Red-Yellow Latosols with sandy texture evaluated 60 days after sowing (OLIVEIRA et al., 2013).

A higher H/CD ratio (7.58) was obtained in the absence of CRF. This occurred because the height variable (H) was not significantly influenced by the CRF doses, different from the diameter, which presented quadratic behavior. This meant that the curve of the H/CD ratio maintained the same standard as the CD, however with opposed concavity. A similar result was observed by Brondani et al. (2018) for Anadenanthera colubrina. The authors found the values of the ratio between 7.1 and 7.6 when testing doses between 0 and $4 \mathrm{~kg} \mathrm{~m}^{-3}$ of the CRF formulation 14-14-14, respectively. However, the control obtained the lower value.

For Araucaria angustifolia (Bert.) O. Ktze. seedlings, the use of CRF provided values between 6.13 and 8.73 for the $\mathrm{H} / \mathrm{CD}$ ratio, with doses of 6 and $9 \mathrm{~kg} \mathrm{~m}^{-3}$, respectively. When evaluating the initial growth of Ocotea odorifera (Vellozo) Rohwer with the same doses, Rossa et al. (2011) observed values between 5.43 and 6.39 in this order. These studies indicate that there is variability in this ratio depending on the species studied, the type of CRF and the time for total nutrient release.

The CRF dose that lead to the highest DQI value (18.87) was $5.37 \mathrm{~kg} \mathrm{~m}^{-3}$ of substrate, different to the control treatment without addition of fertilizer, in which a lower index (12.85) was obtained. Therefore, this indicates that CRF promotes an increase in seedling quality.

\section{CONCLUSION}

- For the production of Moringa oleifera seelings, controlled release fertilizer at a dose of $5.37 \mathrm{~kg} \mathrm{~m}^{-3}$ of substrate is recommended, due to its presenting higher DQI. 


\section{REFERENCES}

ARANTES, C.C. et al. Diferentes formas de aplicação da semente de Moringa oleifera no tratamento de água. Revista Brasileira de Engenharia Agrícola e Ambiental, Campina Grande, v. 19, n. 3, p. 266-272, 2015.

BASRA, S.M.A. et al. Biomass production and nutritional composition of Moringa oleifera under different cutting frequencies and planting spacings. International Journal of Agriculture and Biology, Faisalabad, v. 17, n. 5, p. 1814-9596, 2015.

BRONDANI, G.E. et al. Fertilização de liberação controlada no crescimento inicial de angico-branco. Scientia Agraria, Curitiba, v. 9, n. 2, p. 167-176, 2008.

CECONI, D.E. et al. Exigência nutricional de mudas de erva-mate (Ilex paraguariensis A. St.-Hil.) à adubação fosfatada. Ciência Florestal, Santa Maria, v. 17, n. 1, p. 25-32, 2007.

CHEN, S. et al. Preparation and characterization of slow-release fertilizer encapsulated by biochar-based waterborne copolymers. Science of The Total Environment, s. 1, v. 615, n. 15, p. 431-437, 2018.

CRUZ. C.D. Genes Software - extended and integrated with the R, Matlab and Selegen. Acta Scientiarum. Agronomy, Maringá, v. 38, n. 4, p. 547-552.

DELARMELINA, W.M. et al. Diferentes substratos para a produção de mudas de Sesbania virgata. Floresta e Ambiente, Seropédica, v. 21, n. 2, p. 224-233, 2014.

DICKSON, A.; LEAF, A.L.; HOSNER, J.F. Quality appraisal of white spruce and white pine seedling stock in nurseries. The Forestry Chronicle, Mattawa, v. 36, n. 1, p. 10-13, 1960.

GOPALAKRISHNAN, L.; DORIYA, K.; KUMAR, D.S. Moringa oleifera: A review on nutritive importance and its medicinal application. Food Science and Human Wellness, Pequim, v. 5, n. 2, p. 49-56, 2016.

HE, M. et al. Analysis on soil seed bank diversity characteristics and its relation with soil physical and chemical properties after substrate addition. Plos One, Henan, v. 11, n. 1, p. e0147439, 2016.

HUBER, D. M.; JONES, J. B. The role of magnesium in plant disease. Plant and Soil, Berlim, v. 368, n. 1, p. 73-85, 2013.

LANG, A. et al. Aplicação de fertilizante de liberação lenta no estabelecimento de mudas de ipê-roxo e angico-branco em área de domínio ciliar. Revista Floresta, Curitiba, v. 41, n. 2, p. 271-276, 2011.

LEONE, A. et al. Cultivation, genetic, ethnopharmacology, phytochemistry and pharmacology of Moringa oleifera leaves: an overview. International Journal of Molecular Sciences, Hubei, v. 16, n. 6, p. 12791-835, 2015.

LEONE, A. et al. Moringa oleifera seeds and oil: characteristics and uses for human health. International Journal of Molecular Sciences, Bethesda, v. 17, n. 12, p. 2141, 2016.

MARANA, J.P. et al. Índices de qualidade e crescimento de mudas de café produzidas em tubetes. Ciência Rural, Santa Maria, v. 38, n. 1, p. 39-45, 2008.

NDABIGENGESERE, A.; NARASIAH, K.S.; TALBOT, B.G. Active agents and mechanism of coagulation of turbid waters using Moringa oleifera. Water Research, Delft, v. 29, n. 2, p. 703-710, 1995.

OLIVEIRA, F.A. et al. Crescimento de mudas de moringa em função da salinidade da água e da posição das sementes nos frutos. Revista Árvore, Viçosa, v. 37, n. 1, p. 79-87, 2013.

FLORESTA, Curitiba, PR, v. 48, n.3. p. 303- 310, jul/set. 2018

Rosa. T.L.M. et.al.

ISSN eletrônico 1982-4688 
PACHECO, N.A. et al. Different responses of the quality parameters of Coriandrum sativum to organic substrate mixtures and fertilization. Agronomy, Basel, v. 6, n. 2, p. 21, 2016.

PINTO, C.H.C. et al. Obtenção do biodiesel de Moringa oleifera Lam e do ecodiesel na proporção B5, B10, B20 E B30. Química: ciência, tecnologia e sociedade, Mossoró, v. 1, n. 2, p. 49-60, 2012.

ROSSA, Ü.B. et al. Fertilizante de liberação lenta no crescimento de mudas de Araucaria angustifolia e Ocotea odorifera. Revista Floresta, Curitiba, v. 41, n. 3, p. 491-500, 2011.

SÁNCHEZ-MARTÍN, J.; BELTRÁN-HEREDIA, J.; PERES, J.A. Improvement of the flocculation process in water treatment by using Moringa oleifera seeds extract. Brazilian Journal of Chemical Engineering, São Paulo, v. 29, n. 3, p. 495-502, 2012.

TIAN, C. et al. Effects of a controlled-release fertilizer on yield, nutrient uptake, and fertilizer usage efficiency in early ripening rapeseed (Brassica napus L.). Journal of Zhejiang University-SCIENCE B, Zhejiang, v. 17, n. 10, p. 775786, 2016.

VIEIRA, A. M. S. et al. Use of Moringa oleifera seed as a natural adsorbent for wastewater treatment. Water, Air, and Soil Pollution, s. 1, v. 206, n. 1, p. 273-281, 2010.

VIEIRA, H.; CHAVES, L.H.G.; VIÉGAS, R.A. Acumulação de nutrientes em mudas de moringa (Moringa oleifera Lam) sob omissão de macronutrientes. Revista Ciência Agronômica, Fortaleza, v. 39, n. 1, p. 130-136, 2008.

VIEIRA, H.; CHAVES, L.H.G.; VIÉGAS, R.A. Diagnóstico de sintomas de deficiência de macronutrientes em mudas de moringa (Moringa oleifera). Cerne, Lavras, v. 13, p. 47-53, 2007. 